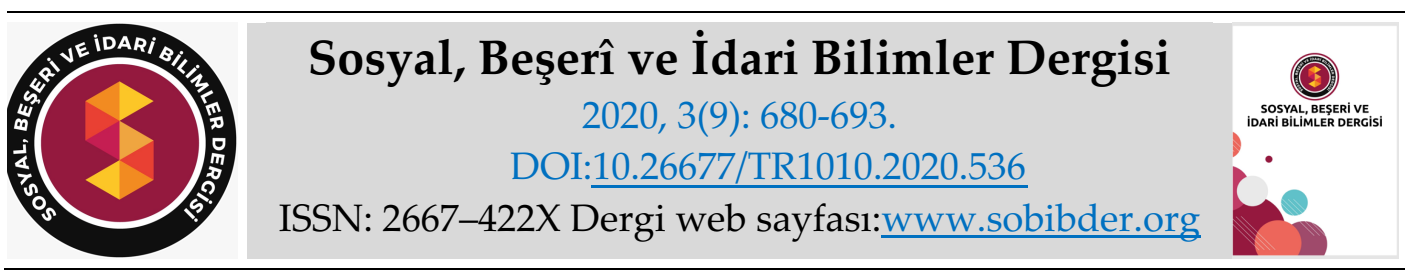

ARASTTIRMA MAKALESI

\title{
Yeni Tebliğler Kapsamında Muhasebe Meslek Mensuplarının E-Dönüşüm Algılarının İncelenmesi: Uşak İli Örneği
}

Dr. Öğr. Üyesi Fatma AKYÜZ, Uşak Üniversitesi, İktisadi ve İdari Bilimler Fakültesi, Uşak, eposta: fatma.akyuz@usak.edu.tr

ORCID: https://orcid.org/0000-0002-7309-1586

Öz

$\mathrm{Bu}$ çalışmada muhasebe meslek mensuplarının E-Dönüşüm hakkındaki algılarının değerlendirilmesi amaçlanmıştır. Özellikle muhasebe kayıtlarda ve ispat edici belgelerin düzenlenmesinde hata veya hile olaylarının en aza indirilebilmesi ve kontrolün insan gücüyle değil de elektronik sistem üzerinden yapılması gerekliliği E-Dönüşümü gerekli kılmıştır. Bu çerçevede Hazine ve Maliye Bakanlığının kayıt dışı ekonomiyi tespit edebilmek, vergi kayıp ve kaçaklarını önleyebilmek, aktif bir denetim sistemini tesis edebilmek, olabilecek hilelere zamanında müdahale edebilmek gibi amaçlar ile muhasebede E-Dönüşüm uygulamaları gerçekleştirmektedir. Çalışmanın amacı kapsamda öncelikle E-Dönüşümün gerekliliği ve EDönüşüm geçiş süreci, E-Fatura, E-Arşiv Fatura, E-Defter, E-İrsaliyenin dijital dönüşümün muhasebe meslek mensupları açısından önemi açıklanmaya çalışılmışır. Ardından çalışmada EDönüşüm hakkında literatür taraması yapılmıştır. Araştırma kapsamında Uşak ilinde faaliyet gösteren Serbest Muhasebeci Mali Müşavir (SMMM) unvanlı bağımsız olarak çalışan 140 muhasebe meslek mensubuyla yüz yüze anket yöntemi uygulanarak veriler toplanmıştır. Toplanan verilerin analiz edilmesi sonucunda kadın ve erkek uygulama düzeylerinin arasında anlamlı bir farklılık olmadığı görülmüştür.

Anahtar Kelimeler: Muhasebe Meslek Mensubu, E-Dönüşüm, Dijitalleşme.

Makale Gönderme Tarihi: 01.06.2020

Makale Kabul Tarihi: 03.09.2020

\section{Önerilen Atıf:}

Akyüz, F. (2020). Yeni Tebliğler Kapsamında Muhasebe Meslek Mensuplarının E-Dönüşüm Algılarının İncelenmesi: Uşak İli Örneği, Sosyal, Beşeri ve İdari Bilimler Dergisi, 3(9): 680-693.

(C) 2020 Sosyal, Beşerî ve İdari Bilimler Dergisi. 


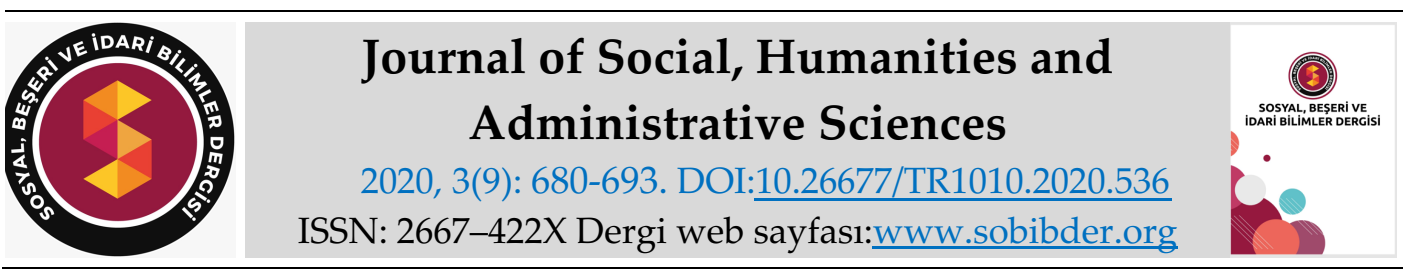

RESEARCH PAPER

\title{
Investigation of E-Transformation Perceptions of Accounting Professional Members Within the Scope of New Communiques: Case of Uşak
}

Assistant Prof. Dr. Fatma AKYÜZ, Uşak University, Faculty of Economics and Administrative Sciences, Uşak, e-mail: fatma.akyuz@usak.edu.tr ORCID: https://orcid.org/0000-0002-7309-1586

\begin{abstract}
In this study, it is aimed to evaluate the perceptions of professional accountants about ETransformation. E- Transformation required the necessity of minimizing the error or cheating events especially in the accounting records and editing the proof documents and making the control over the electronic system, not manpower. In this context, E-Transformation practices are carried out in accounting for purposes such as detecting the informal economy of the Ministry of Treasury and Finance, preventing tax losses and smuggling, establishing an active control system, and intervening in possible tricks in a timely manner. The aim of the study is primarily to explain the necessity of E-Transformation and the E-Transformation transition process, EInvoice, E-Archive Invoice, E-Ledger, and the importance of digital transformation of E-Dispatch for professional accountants. Then, in the study, a literature review was made about ETransformation. Within the scope of the research, data were collected by applying face-to-face questionnaire with 140 independent accountants working independently with the title of CPA Certified Public Accountant operating in the city of Uşak. As a result of analyzing the collected data, it was seen that there was no significant difference between the levels of male and female application.
\end{abstract}

Keywords: Accounting Profession Member, E-Transformation, Digitalization.

Received: 01.06.2020

Accepted: 03.09.2020

\section{Suggested Citation:}

Akyüz, F. (2020). Investigation of E-Transformation Perceptions of Accounting Professional Members Within the Scope of New Communiques: Case of Uşak, Journal of Social, Humanities and Administrative Sciences, 3(9): ?-?.

(C) 2020 Sosyal, Beşerî ve İdari Bilimler Dergisi. 


\section{Gíriş}

Günümüzde teknolojinin hızlı ve sürekli olarak değişimi yaşanmaktadır. Bu değişimden tüm sektörler etkilendiği gibi, muhasebe bilimi ve uygulamaları da etkilenmektedir. Değişime toplum olarak ilk aşamada direnç gösterilse de zamanla bu değişimin getirdiği olumlu etkiler fark edilmiştir. Kamu sektöründe yaşanan değişimlere uyumun hızlı gerçekleşmesinden dolayı işlemlerin elektronik ortama aktarılması ve kontrolü de sağlanabilmektedir. Yaşanan bu değişimler muhasebe uygulamalarında E-Dönüşümü gerekli kılmaktadır.

Muhasebe uygulamalarında yaşanan ilk değişim var olan işlem ve belgelerin önüne 'E' harfiyle başlamıştır. Dünyada birçok ülkede muhasebe uygulamalarında E-Dönüşüm çok önceden başlamasına rağmen ülkemizde bu dönüşüm yeni sayılmaktadır. Aslında birçok üniversitede ders programları içinde E-Dönüşüme yönelik uygulama çalışmaları yapılırken, çalışma hayatına bu bilgilerin aktarılması ve uygulamaya geçirilmesi yavaş gerçekleşmektedir. Bu noktada muhasebe meslek mensuplarının E-Dönüşüm hakkındaki farkındalıklarını artırmaları, düzenlenecek E-Belgeler hakkında fikir ve bilgi sahibi olmaları, konu hakkında çalıştay, seminer, konferans programlarına katılım sağlanması, sürece geçişi hızlandıracağı gibi, geçiş döneminin olabildiğince sorun yaşanmadan atlatılmasını da sağlayacaktır.

Çalışmanın bu kapsamda amacl; muhasebe meslek mensuplarının E-Dönüşüm hakkındaki farkındalıklarını tespit etmektir. Çalışmada ilk aşamada E-Dönüşüm hakkında bilgi verilerek, düzenlenen belgelerin E-Dönüşme geçişi hakkında açıklamalarda bulunulmuştur. Çalışmanın ikinci aşamasında ise muhasebe meslek mensuplarının E-Dönüşüm hakkındaki farkındalıklarını belirleyebilmek amacıyla anket çalışmasından oluşmaktadır. Anket çalışması için Uşak Üniversitesi Sosyal ve Beşeri Bilimler Bilimsel Araştırma ve Yayın Etiği Kurulundan 89784354050.99 Sayılı kararı ile çalışmada kullanılacak olan anket için etik açısından uygun olduğuna dair onay alınmıştır. Anket çalışması Uşak ilinde faaliyette bulunan 140 muhasebe meslek mensubuna yapılmıştır. Uşak SMMM odasından alınan bilgiler doğrultusunda aktif olarak çalışan SMMM sayısı 193 kişi olmasına rağmen, iş yoğunluğu nedeniyle anket çalışmasına katılmak istemeyen ve anket sorunlarının bazılarına cevap vermek istemeyen muhasebe meslek mensupları olduğu için çalışma 140 SMMM üzerinden değerlendirilmeye alınmıştır. Anketin güvenirliliğini ve geçerliliğini test etmek için örnek olarak seçilmiş 25 muhasebe meslek mensubu üzerinde yapılmıştır. Anket çalışması 11.03.2020-18.03.2020 tarih aralığında yapılmıştır. Anketlerden elde edilen verilerin değerlendirmesi SPSS for Windows 22.0 programı aracılığıyla analiz edilmiştir. Çalışmanın sonucunda anket çalışmasına katılan 140 Muhasebe meslek mensuplarının kadın ve erkek uygulama düzeylerinin arasında anlamlı bir farklılık olmadığı görülmüştür. Aynı zamanda mensuplarının öğrenim durumları ile E-Dönüşüm uygulamaları yargılarına katılım düzeyinin ortalamaları arasında anlamlı bir farklılık olmadığı sonucuna ulaşılmıştır. Diğer taraftan Muhasebe meslek mensuplarının E-Dönüşüm uygulamaları yargılarına katılım düzeyinin karşılaştııılması sonrasında bağımlı çalışan ve bağımsız çalışan katılımcıların uygulama düzeyleri ve E-Dönüşüm uygulamaları yargılarına katılım düzeyinin karşılaştırılması sonrasında programlara katılan katılımcıların ve katılmayan katılımcıların uygulama düzeyleri arasında anlamlı bir farklılık olduğu sonucuna ulaşılmıştır. Aynı zamanda Muhasebe meslek mensuplarının E-Dönüşüm kullanım düzeyleri ile E-Dönüşüm uygulamaları yargılarına katılım düzeyinin ortalamaları arasında anlamlı bir farklılık olduğu sonucuna ulaşılmıştır.

\section{MUHASEBE MESLEĞİNDE E-DÖNÜŞÜM GEREKLİLİĞİ ve MUHASEBE MESLEK MENSUPLARININ E-DÖNÜŞÜME GEÇIŞ SÜRECİ}

Günümüzde dış dünyanın hızlı değişimine uyum sağlanmak zorunda olunması ve çoğunlukla alışverişlerin online olarak gerçekleştiği bir ortamda değişikliklere hemen adapte olmak gerekmektedir. Birçok alan bu değişikliklere ihtiyaç olduğu için kendiliğinden hemen uyum 
sağlarken, bazı alanlarda ise belli bir zaman aralığının geçmesi gerekmektedir. Bazen de bu durum yasal olarak değişikliklere uyum sağlamayı zorunluluk olarak getirmektedir. Muhasebe mesleğinin de dijital anlamda dönüşüm yaşaması, ihtiyaçların karşılanma biçimindeki değişiklikler, hata ve hile olasılığını en aza indirmek, vergi kayıplarının önüne geçebilmek ve etkin bir denetim ve kontrol sistemini uygulamaya koyabilmek anlamında gerekmektedir.

Muhasebe mesleğinde gelişen teknolojilere uyum sağlayabilmek anlamında E-Dönüşüm sürecinde birçok yeni kavramla karşı karşıya kalınmıştır. Bununla birlikte muhasebe mesleğinin geçmişteki önemi de düşünülecek olursa, gelecekte de muhasebe mesleğinin yeniliklere açık ve sürekli yeni gelişmeleri takip edebilmesi gerekmektedir. Bu noktada sürecin önemi nitelikli eleman yetiştirilmesinden başlayıp, denetim faaliyetlerin etkin gerçekleşmesine kadar olan süreci kapsadığı görülmektedir.

Muhasebe mesleğindeki E-Dönüşümünden faydalanabilecek kişi veya kurumlar, Borsa'da faaliyet gösteren şirketler, vergi denetçileri, Sermaye Piyasası Kurulu, Türmob, Bankalar, Ticaret Mahkemeleri vs. olarak sıralanabilir. Bu kapsamda düzenlemelerin E-Dönüşüm açısından neler olduğu ve şekil açısından farklılıklarının bilinmesi gerekmektedir.

E-Fatura: Kağıt ortamında hazırlanan faturanın elektronik ortamda oluşturulmasıdır. Böylelikle sözkonusu faturanın kontrolü sağlanabilirken, işlem gerçekleştiği anda kayıtlara aktarımı yapılabilmektedir. Faturada yer alan bilgilerin kontrolü doğrultusunda vergi kaçakçllı̆ı̆nın önlenmesi, her işlemin kayıt altına alınabilmesi ve hızlı bir şekilde işlemlerin gerçeklemesi sağlanmak amaçlanmıştır (Elçin vd., 2018: 15-16). E- Fatura kullanımının sağladığı diğer faydalar ise; kağıt kullanımını azaltması, belgelerin saklama ve arşivleme maliyetlerini düşürmesi ve ihtiyaç duyulduğu her zaman fatura bilgilerine her yerden ulaşılabilmesidir (Gökçen ve Özdemir, 2016: 146). Muhasebe mesleğinin dünyadaki gelişim süreci incelendiğinde birçok ülkede E-Dönüşüm sürecin uzun yıllar öncesi başlamıştır. Finlandiya ilk olarak E-Fatura sistemine geçen ülke olurken, ikinci sırayı Estonya takip etmektedir. Türkiye ise sağlık sektörünün E-Sisteme geçişi esas alınacak olursa 2012 yılında pilot uygulama olarak başlatılan sistem 15 Ocak 2013 tarihinde zorunluluk haline gelmiştir (Akıcı ve Altun; 2013: 125-126).

E-Arşiv Fatura: Hazine ve Maliye Bakanlığı'nın 30923 Sayılı Resmi Gazete Tebliği ve Vergi Usul Kanunu Genel Tebliği Sıra No:509' a göre ‘Bu tebliğ yer alan şartlara uygun şekilde elektronik ortamda oluşturulan ve e-Fatura dışında kalan elektronik faturaları' kapsamaktadır. Bu tebliğ kapsamında EArşiv fatura uygulayacak olan mükelleflerin, E-Fatura uygulamasına dahil olmayan vergi mükellefleri ve nihai tüketici ve bazen yurtdışı alıcılara (özellikle hizmet alıcıları) düzenlenen faturaların da elektronik ortamda oluşturulmasıdır. E-Arşiv fatura aslında kağıt ortamında oluşturulan fatura ile aynı mahiyette olan bir belgedir(https://www.gib.gov.tr/sites/default/files/fileadmin/mevzuatek/vukteb509.pdf).

E-Defter: 17.02.2020 tarihinde Gelir İdaresinin E-Defter bilgilendirme duyurusuna göre E-Fatura uygulamasına geçme zorunluluğu getirilen mükellefler ile Türk Ticaret Kanununun 397'nci maddesinin dördüncü fıkrası gereğince bağımsız denetime tabi olan şirketler için E-Defter tutma yükümlülüğü getirilmiştir (http://edefter.gov.tr/dosyalar/duyurular/eDefter_Bilgilendirme_Duyurusu.pdf).

E-İrsaliye: 'Mal hareketlerinin elektronik ortamda düzenli bir şekilde izlenebilmesi amacıyla Kanununun 230'uncu maddenin birinci fikrasının beşinci bendine göre hali hazırda kă̆gt ortamda düzenlenmekte olan "sevk irsaliyesi" belgesinin, elektronik belge olarak elektronik ortamda düzenlenmesi, alıcısina elektronik ortamda iletilmesi ve elektronik ortamda muhafaza ve ibraz edilmesine ilişkin yapılan düzenlemelerdir' (https://www.gib.gov.tr/sites/default/files/fileadmin/mevzuatek/vukteb509.pdf). 
Muhasebe mesleğinin dijital dönüşüme geçişi uzun zamandan beri duyulan bir gereksinim olsa da geçiş süreci hemen gerçekleşmemektedir. Bu noktada ilk etapta geçiş için ilgili taraflara bilgilendirilmelerin yapılması, bu süreçte kendilerine hangi bilgileri ve belgeleri hazırlamaları gerekliliğinin açıklanması ve E-Dönüşümün faydasının anlatılması gerekmektedir.

VUK 509 göre yıllık ciroya ve meslek gruplarına göre E-Sisteme geçiş tarihleri belirlenmiştir. Madde 353 Özel Usulsüzlükler ve Cezaları kapsamında 'Elektronik belge olarak düzenlenmesi gerekenler de dâhil olmak üzere, verilmesi ve alınması icabeden fatura, gider pusulası, müstahsil makbuzu ile serbest meslek makbuzlarmın verilmemesi, alınmaması, düzenlenen bu belgelerde gerçek meblağdan farklı meblağlara yer verilmesi, bu belgelerin elektronik belge olarak düzenlenmesi gerekirken Maliye Bakanlı̆̆ınca belirlenen zorunlu haller hariç olmak üzere kâğıt olarak düzenlenmesi ya da bu Kanunun 227 nci ve 231 inci maddelerine göre hiç düzenlenmemiş sayılması halinde; bu belgeleri düzenlemek ve almak zorunda olanların her birine, her bir belge için 240 (513 Stra No.lu V.U.K Genel Tebliği ile 1.1.2020'dan itibaren 350 TL) Türk lirasından aşă̆ı olmamak üzere bu belgelere yazllması gereken meblağın veya meblağ farkının \%10'u nispetinde özel usulsüzlük cezası kesilir' şeklinde karar alınmıştır (Madde 353 Özel Usulsüzlükler ve Cezaları, https://www.gib.gov.tr/node/83111).

Vergi Usul Kanunu uyarınca düzenlenmesi zorunlu olan elektronik belge uygulamalarına yönelik zorunlu geçiş tarihlerinin ve uygulama esaslarının yer aldığ 509 Sıra No.lu Vergi Usul Kanunu Genel Tebliği 19.10.2019 tarihinde 30923 Sayılı Resmi Gazetede yayınlanmıştır. Buna göre VUK 509 Kapsamında E-Uygulamalara Geçiş Tarihlerinde; E-Faturaya geçiş zorunluluğu olanlar ve mükelleflerde E-Arşiv ve E-Defter için 1 Ocak 2020, E- Müstahsil Makbuzu için 1 Temmuz 2020, 2018 Hesap Dönemi Brüt Satış Hasılatı (veya satışları ile gayrisafi iş hasılatı) 10 Milyon TL ve üzeri olan mükelleflerde E-Fatura, E-Arşiv ve E-Defter için 1 Ocak 2020, EMüstahsil Makbuzu içi 1 Temmuz 2020, 2018 ve 2019 Yılı Brüt Satış Hasılatı 5 Milyon ve üzeri olanlar E-Fatura, E- Arşiv, E-Müstahsil Makbuzu 1 Temmuz 2020, E-Defter için 1 Ocak 2021, 2018 Brüt Satış Hasılatı 25 Milyon ve üzeri olanlar E-Fatura, E-Arşiv, E-Defter için 1 Ocak 2020, Eİrsaliye ve E-Müstahsil Makbuzu için 1 Temmuz 2020, Bağımsız denetime tabi olanlar için EDefter 1 Ocak 2020, E-Arşiv Fatura uygulamasına dahil olmayan mükelleflerce, düzenlenecek faturaların, vergiler dahil toplam tutarının 30 Bin TL'yi (vergi mükelleflerine düzenlenenler açısından vergiler dahil toplam tutarı 5 Bin TL'yi) aşması halinde, söz konusu faturalarda E-Arşiv 1 Ocak 2020, E-Fatura uygulamasina kayıtlı olan ve Hal kayıt sistemi kapsamında sebze ve meyvelerin ticareti ile iştigal eden tüccar ve komisyoncularda E-Fatura, E-Arşiv, E-İ̈saliye, EMüstahsil Makbuzu için 1 Ocak 2020, Tüm serbest meslek erbapları (avukat, mali müşavir, serbest çalışan doktor, mimar, mühendisler vb.) için E-Serbest meslek makbuzu 1 Temmuz 2020, Demir çelik sektörü ve gübre takip sistemi kapsamında bulunan mükellefler için E-İrsaliye 1 Temmuz 2020'dir. (https://www.verginet.net/dtt/11/Vergi-Sirkuleri-2019-124.aspx).

\section{LITTERATÜR}

Muhasebede elektronik dönüşüm ve uygulamaları konusunda yapılan belli başlı çalışmalara ait bulgular aşağıda yer almaktadır.

Çıtak ve Baskan (2020); Muhasebe uygulamalarındaki elektronik gelişmelerin muhasebe meslek etiğine etkisini araştırdıkları çalışmalarında anket yöntemini kullanmışlardır. Bu noktada Kırkkale Serbest Muhasebeci Mali Müşavirler Odasına kayıtlı muhasebe meslek mensuplarının görüşlerini tespit etmeye çalışmışlardır. Çalışma 322 meslek mensubundan 51'i ile online anket üzerinden gerçekleşmiştir. Çalışmanın sonucunda katılımcıların \%56'sının E-Dönüşüm uygulamalarının meslek etiğini etkileyebileceğini, \%72'sinin E-Dönüşüm uygulamalarının mesleki özeni destekleyebileceğini, \%56'sının E-Dönüşüm uygulamalarında çalışanların altyapı 
eksikliğinin muhasebe meslek etiği davranışını etkileyebileceğini, \%55'nin ise eğitim almayan meslek mensuplarının meslek etiği anlayışını etkilediği sonucuna ulaşmışlardır. Çalışmanın sonunda E-Dönüşüm uygulayacakların E-Dönüşüm ile ilgili eğitim almalarının etik davranışı etkileyebileceğini tespit etmişlerdir.

Karasioğlu ve Garip (2019); Çalışmada muhasebede E-Dönüşüm ve uygulamaları hakkında bilgi verilerek E-muhasebe uygulamalarında karşılaşılan sorunlar açıklanmıştır. Çalışmada geniş bir literatür taraması yapılarak uygulama için anket yöntemi tercih edilmiştir. Çalışma Karaman SMMM odasına kayıtlı 206 meslek mensubundan 191 meslek mensubu üzerinde gerçekleşmiştir. Çalışmanın örnek büyüklüğü 127,79 olarak hesaplanmış olup, geçerliliği kabul edilen 138 meslek mensubuna olarak belirlenmiştir. Çalışmanın bulguları olarak; GIB portal üzerinden EUygulamalara ulaşma oranının yüksek olduğu, bilgilenme toplantılarına katılanların ise genellikle Karaman SMMM odasından olduğu görülmüştür. E-Dönüşüm uygulamalarında yeterli altyapı ve bilgi eksikliklerinden dolayı hata yapma ihtimalinin yüksek olmasının iş performansını olumsuz etkilediği sonucuna ulaşmışlardır.

Allahverdi ve Karaer (2019), Muhasebe mesleği için alınması gereken becerilerin neler olduğunun belirlenmesi ve düzeylerinin tespit edilmesini amaçladıkları çalışmada, Türkiye'de bulunan lisans düzeyinde eğitim veren 64 üniversitenin işletme bölümleri incelenmiştir. Çalışmada; muhasebe adaylarının sahip olması gereken yeterlilikler mesleki beceriler, işletme bilgisi becerisi, genel bilgi becerileri, mesleki etik, tutum ve davranış yeterlilikleri, teknolojik beceriler olarak sınıflandırmıştır. Çalışmanın sonucunda; temel seviyedeki dersler için muhasebe meslek adaylarının bilgisayar kullanma yeteneklerini geliştirmeleri, orta seviyedeki adaylar için temel seviyedeki dersleri tamamlamak gerekliliği ve finansal muhasebe, maliyet muhasebesi, mali tablolar, vergi, veri tabanı yönetim yazılımı gibi derslerin alınması gerekliliği, ileri seviye için alt seviyeleri tamamlayarak son sınıfta olan muhasebe meslek adayları için ise, ERP yazılımları eğitimi için uygun ortamın sağlanması, genelleştirilmiş denetim yazılımları, bulut bilişim eğitimi önerilmiştir.

Calayoğlu (2019); Çalışmanın amacını E-Dönüşüm sürecinde vergi denetimindeki risk odaklı mevcut elektronik uygulamaları ve sonuçlarını derlemek, yorumlamak, vergi denetimlerini tam elektronik olarak açıklamak, meslek mensubu, mükellef ve araştırmacıların gelecekteki süreç ve uygulamalar hakkında bilgi edinilmesini sağlamaktır. Çalışmada E-Vergi uygulamalarının öneminden bahseden çalışmada denetim uygulamalarının daha aktif hale gelmesi ve vergi dairelerinin sorumluluğunda olan vergi mevzuatına göre hareket edilip/edilmediğini denetleme işleviyle yerine getirilebileceği ifade edilmiştir.

Çarıkçı (2018), Isparta ve Burdur ilinde faaliyet gösteren meslek mensuplarının Defter-Beyan sistemindeki değişiklikler hakkındaki düşüncelerine, endişelerine ve önerilerine yönelik çalışma yürütmüştür. Çalışmanın sonucunda meslek mensuplarının Maliye Bakanlığının başlatmış olduğu kayıtlar ile defterlerin elektronik ortamda tutulmasına yönelik ciddi kaygılar taşıdıklarına ulaşmışlardır.

Liyan (2013), internet kullanımının artmasıyla beraber alışverişlerin internet ortamında yapılmasının sonucunda elektronik fatura kullanımının arttığını ifade eden çalışmada, yeni kayıt sistemi olarak elektronik muhasebe bilgisine sahip olan meslek mensup ihtiyacının hissedildiği ifade edilmiştir.

Türker (2018), Muhasebe mesleğinin küresel gelişim sürecinden ve küresel muhasebe denetimden bahsedilen çalışmada, muhasebe mesleğinin dijitalleşme sürecinden nasıl etkilendiğini ve özellikle iş dünyasının hızlı karar alabilme ve sürece hızla uyum sağlanması konusuna yönelik çalışmalarına muhasebe biliminin de dahil olması gerektiği vurgulanmıştır. Çalışmanın sonucunda yapay zeka, blokzincir ve megatrendeler çerçevesinde muhasebe meslek 
örgütlerin dijitalleşme konusunda hızlı hareket etmeleri gerektiğini ve muhasebe mesleğinin yeniden ve nasıl yapılandırılabileceği konusunda çalışmalar yapmaları gerektiği vurgulanmıştır.

\section{ARAŞTIRMA YÖNTEMI}

\section{Araştırma Verilerinin Toplanması ve Verilerin Analizi}

Çalışmada Muhasebe meslek mensuplarının E-Dönüşüm ölçeği, Öztürk ve Çarıkçı (2018) tarafından geçerliliği ve güvenirliliği test edilen 'Büyük ve Orta Boy İşletmeler İçin Finansal Raporlama Standardının Muhasebe Meslek Mensupları Üzerinde Algı Düzeyinin Araştırılması' başlıklı çalışmasından uyarlanmıştır. Referans olarak oluşturulmuş anket formu, geçerli örnekleme ulaşabilmesi amacıyla ifadeler yeniden düzenlenmiştir.

Çalışmada elde edilen veriler SPSS for Windows 22.0 programı aracılığıyla elde edilmiştir. Ankette yer alan ifadelere verilen cevaplar frekans dağılımları belirlenerek değerlendirilmeye alınmıştır. Çalışmada analiz teknikleri olarak SPSS programı üzerinde frekans değerleri, bağımsız grup t-testi, çapraz tablo analizleri, varyans analizi ve güvenilirlik analizleri yapılmıştır.

Anakütleden örnekleme alınacak en uygun sayı hesaplanmıştır ve \%90 güven seviyesinde en az 113 kişiye ulaşılması sonucu çıkmıştır (Kılıç, 2012: 141). TÜRMOB'a kayıtlı Uşak ilindeki SMMM sayısı 361 kişi iken, Uşak SMMM odasından alınan bilgiler doğrultusunda aktif olarak çalışan SMMM sayısı 193 kişidir. Çalışmada iş yoğunluğu nedeniyle anket çalışmasına katılmak istemeyen ve anket sorunlarının bazılarına cevap vermek istemeyen muhasebe meslek mensupları olduğu için çalışma 140 SMMM üzerinden değerlendirilmeye alınmıştır. Anketin güvenirliliğini ve geçerliliğini test etmek için örnek olarak seçilmiş 25 muhasebe meslek mensubu üzerinde yapılmıştır. Anket çalışması 11.03.2020-18.03.2020 tarih aralığında yapılmıştır. Anketlerden elde edilen verilerin değerlendirmesi SPSS for Windows 22.0 programı aracılığıyla analiz edilmiştir.

Tablo 1: Güvenilirlik Analizi Sonucu

\begin{tabular}{|c|r|}
\hline & \multicolumn{2}{|c|}{ Algılanan E Dönüşüm Ölçeği } \\
\hline \hline Cronbach's Alpha &, 817 \\
N of Items & 12 \\
\hline
\end{tabular}

Güvenirlik analizi sonucunda Cronbach's Alpha değeri; E Dönüşüm Ölçeğinde \%77,9 olarak bulunmuştur. Çalışmada Alpha değerinin yeteri kadar yüksek bir güvenilirlik düzeyinde olması için 12. soru çıkarılmıştır ve Cronbach's Alpa değeri \%81,7'ye yükselmiştir. Böylece ölçeğin güvenirlik düzeyi \%81,7 oranda kabul edilmiştir. Sosyal bilimlerdeki çalışmalarda güvenilirlik değerinin \%40 ve \% 60 arasında olmasıyla ölçeğin oldukça güvenilir olarak kabul edildiğini ifade etmişlerdir (Geçkil ve Tikici, 2015: 60).

Tablo 1'deki çıkan sonuçlara göre modifiye edilmiş ölçeklerin güvenilir olduğu kanaatine ulaşılabilir. Güvenilirlik analizi sonrasında; muhasebe meslek mensuplarının demografik özellikleri analiz edilmiş olup, Çapraz Tablo Analizi, Independent Sample T Testi ve Varyans Analizi uygulanmıştır. 


\section{ARAŞTIRMA BULGULARI}

Anket temel olarak dört bölümden oluşmaktadır. Bu bölümler; muhasebe meslek mensuplarının Demografik Özellikler, Çapraz Tablo Analizi, Independent Sample T Testi ve Varyans Analizdir. Anketin ilk bölümünü oluşturan demografik veriler; cinsiyet, yaş dağılımları, çalışma biçimleri, mesleki deneyim, eğitim programlarına katılım, öğrenim durumları değişkenlerinden oluşmaktadır. Demografik bulgular Tablo 2' de gösterilmiştir.

Tablo 2: Muhasebe Meslek Mensuplarına Ait Demografik Bulgular

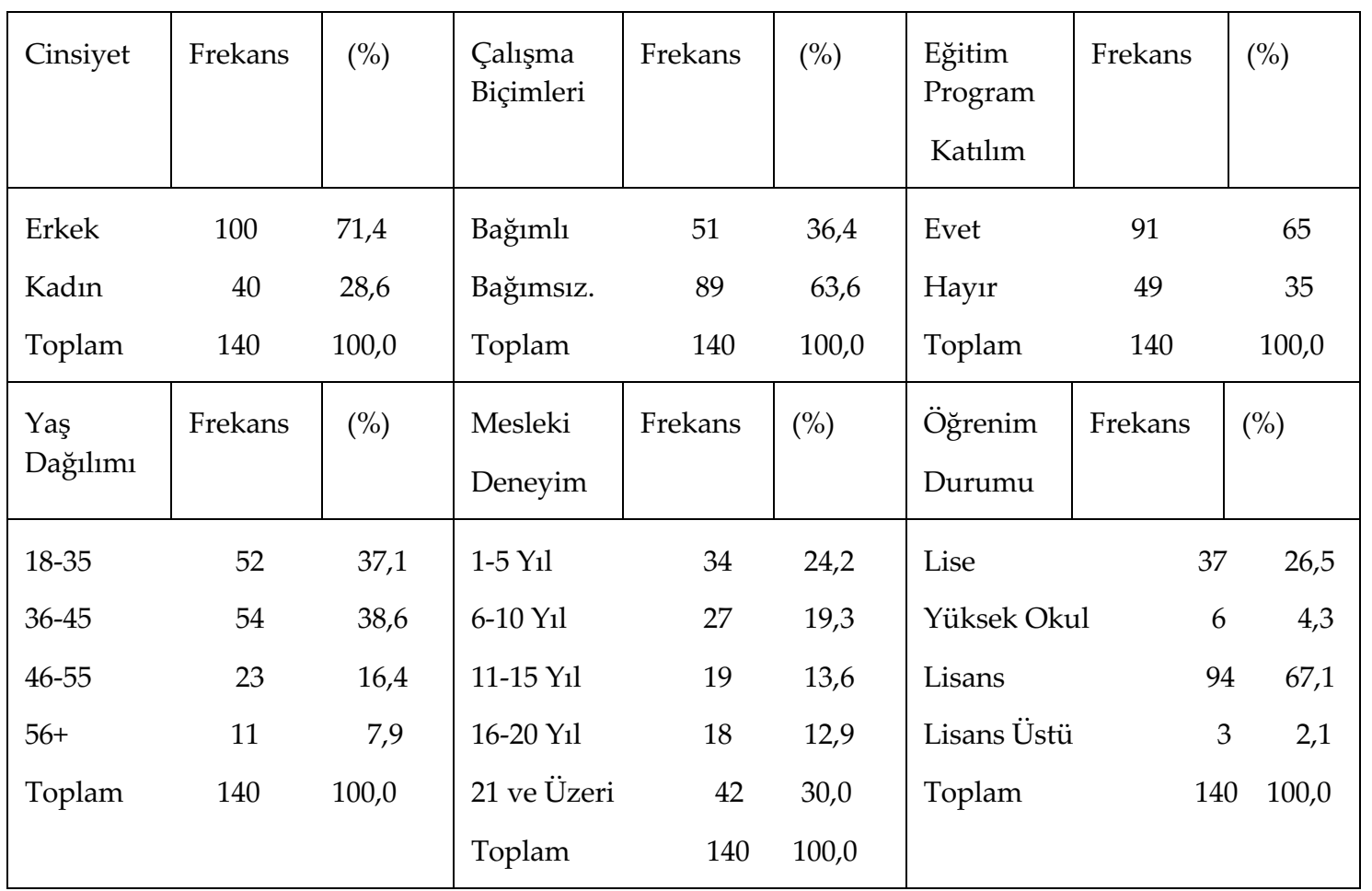

Tablo 2'ye göre 140 muhasebe meslek mensubunun 100'ü (\%71,4) erkek, 40 muhasebe meslek mensubu (\%28,6) kadındır. Muhasebe meslek mensuplarının yaş dağılımları incelendiğinde ise; 52 muhasebe meslek mensubunu (\% 37,1) 18-35 yaş aralığında, 54 muhasebe meslek mensubu (\%38,6), 36-45 yaş aralığında, 23 muhasebe meslek mensubu (\%16,4) 46-55 yaş aralığında, 11 muhasebe meslek mensubu ise $(\% 7,9) 56$ yaş ve üzerindedir. Tablo 2'ye göre muhasebe meslek mensuplarının çalışma biçimleri; 51'i $(\% 36,4)$ bağımlı olarak çalışırken, 89 muhasebe meslek mensubu (\% 63,6) bağımsız olarak çalıştığını ifade etmişlerdir. Ankete katılım sağlayan meslek mensuplarının 91'i (\% 65) eğitim programlarına katılım sağlarken, 49 muhasebe meslek mensubu ise (\% 35) eğitim programlarına katılmamayı tercih ettiklerini belirtmişlerdir. Ayrıca ankete katılan muhasebe meslek mensupları içinde 94 kişinin $(\%$ 67,1) lisans düzeyinde eğitim aldığını, ikinci sırada ise 37 muhasebe meslek mensubunun (\% 26,5) lise mezunu olduğu görülmüştür.

Tablo 3'de görüldüğg̈ gibi; Ankete katılan muhasebe meslek mensuplarının daha önce EDönüşüm için eğitim, seminer, konferans, panel vb. gibi çalışmalara katılımları analiz edildiğinde, 100 erkek muhasebe meslek mensubunun 64'nün $(\% 70,3)$ çalışmalara katılım sağlamasına rağmen, 36 erkek muhasebe meslek mensubunun $(\% 73,5)$ katılım sağlamadığ1 belirlenmiştir. Ankete katılan bayan muhasebe meslek mensuplarının E-Dönüşüm için eğitim, seminer, konferans, panel vb. gibi çalışmalara katılımları analiz edildiğinde ise 27 'sinin $(29,7)$ katılım sağladığı, 13 bayan muhasebe meslek mensubunun ise $(26,5)$ katılım sağlamadığ belirlenmiştir. Toplam olarak E-Dönüşüm için eğitim, seminer, konferans, panel vb. gibi çalışmalara katılımları analiz edildiğinde 140 muhasebe meslek mensubunun 91'i söz konusu 
çalışmalara katılım sağlarken 49 muhasebe meslek mensubunun bu tür çalışmalara katılım sağlamadığı görülmüştür.

Tablo 3: Cinsiyet ile Programlara Katılma Durumu Çapraz Tablo Analizi

\begin{tabular}{|ll|r|r|}
\hline \multirow{2}{*}{} & \multicolumn{2}{|c|}{ Programa Katılma } \\
\cline { 3 - 4 } & Erkek & Dvet & \multicolumn{2}{|c|}{ Hayır } \\
\cline { 3 - 5 } & Kinsiyet & 64 & 36 \\
& Kadın & 27 & $73,5 \%$ \\
& & $29,7 \%$ & 13 \\
& & 91 & $26,5 \%$ \\
\hline Toplam & $100,0 \%$ & 49 \\
& & & $100,0 \%$ \\
\hline
\end{tabular}

Tablo 4'e göre anket çalışmasına katılım sağlayan muhasebe meslek mensuplarının 18-35 yaş aralığında olanların 32'si (\% 35,2), 36-45 yaş aralığında olanların 36'sı (\% 39,6), 46-55 yaş aralığında olan $16^{\prime}$ sı $(\% 17,6)$ ve 56 yaş ve üzerinde olan 7 'sinin $(\% 7,6)$ programlara katılmaya 'Evet' cevabını vermişlerdir. Buna göre en yüksek katılımın 36-45 yaş aralığında olan muhasebe meslek mensupları için gerçekleştiği tespit edilmiştir. Dolayısıyla muhasebe meslek mensuplarının yaşlarıyla programlara katılımın aynı doğrultuda artması gözlemlenmemiştir.

Tablo 4: Muhasebe Meslek Mensuplarının Yaş Gruplarına Göre Programlara Katılma Durumunun Çapraz Tablo Analizi

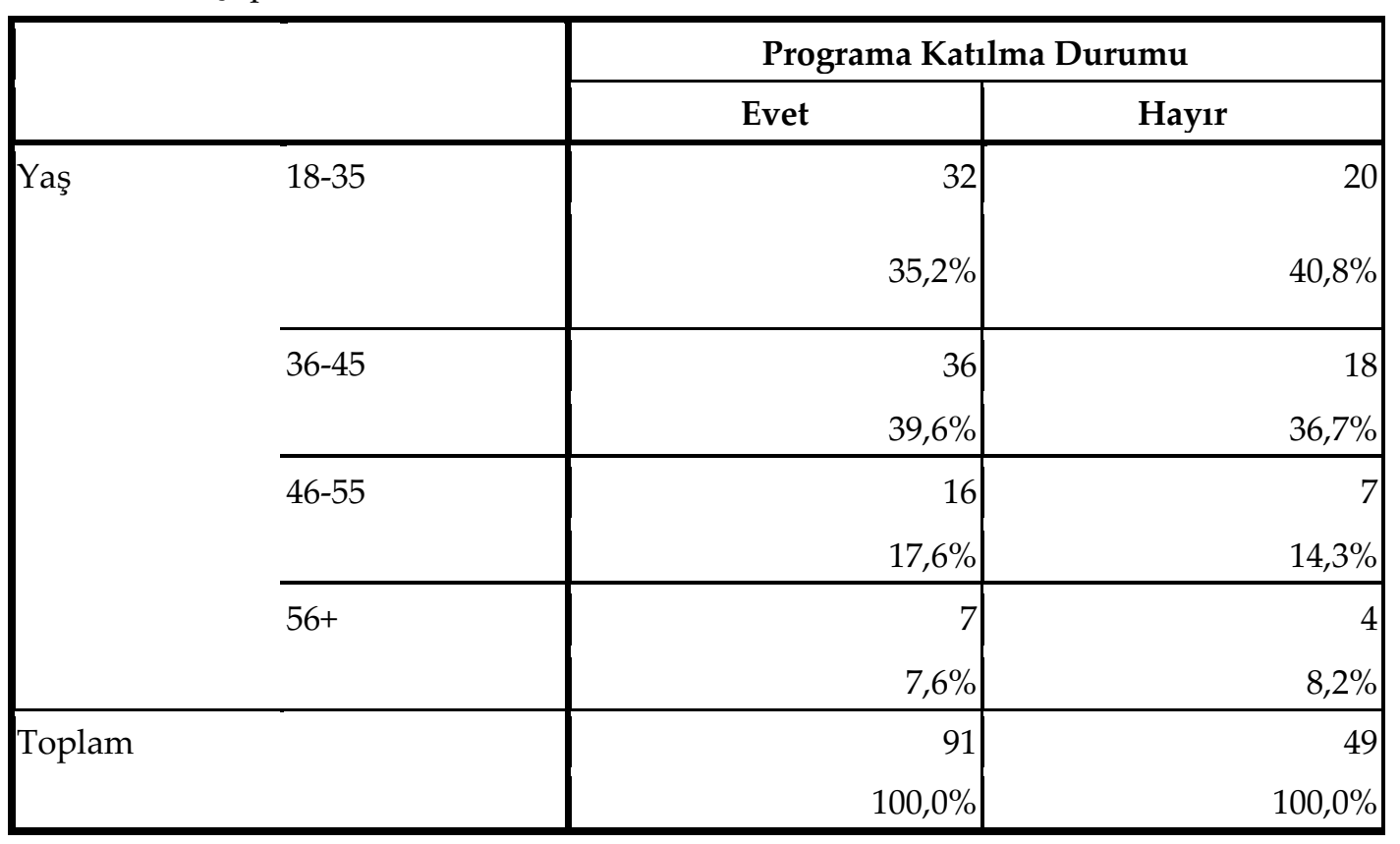

Tablo 5'te ise muhasebe meslek mensuplarının E-Dönüşüm uygulamaları hakkında cinsiyet, çalışma şekilleri ve programlara katılım durumları arasında anlamlı farklılık olup olmadığının test edilmesi amacıyla Independent Sample T testi sonuçları yer almaktadır. Tablo 5'e göre Kadın ve erkek muhasebe meslek mensuplarının E-Dönüşüm düzeylerinin karşılaştırması için yapılan T-testi sonrasında; kadın ve erkek muhasebe meslek mensuplarının uygulama düzeylerinin 
arasında anlamlı bir farklılık olmadığı ancak E-Dönüşüm uygulamaları yargılarına katılım düzeyinin karşılaştırılması sonrasında bağımlı çalışan ve bağımsız çalışan katılımcıların uygulama düzeyleri ve E-Dönüşüm uygulamaları yargılarına katılım düzeyinin karşılaştırılması sonrasında programlara katılan katılımcıların ve katılmayan katılımcıların uygulama düzeyleri arasında anlamlı bir farklılık olduğu sonucuna ulaşılmıştır.

Tablo 5: Independent Sample T Testi Sonuçları Tablosu

\begin{tabular}{|c|c|c|c|c|c|c|}
\hline Grup & $\mathbf{N}$ & Ortalama & Standart Sapma & $\mathbf{T}$ & Df & $\mathbf{P}$ \\
\hline Erkek & 100 & 3,3133 & 66489 & ,916 & 138 & ,361 \\
\hline Kadın & 40 & 3,2000 & 65203 & ,924 & 73,201 & ,359 \\
\hline \multicolumn{7}{|c|}{$\begin{array}{l}\text { Muhasebe Meslek Mensuplarının Çalışma Şekilleri ile E-Dönüşüm Uygulamaları } \\
\text { Yargılarına Katılım Düzeyinin Karşılaştırılması İçin T Test Tablosu }\end{array}$} \\
\hline Grup & $\mathbf{N}$ & Ortalama & Standart Sapma & $\mathrm{T}$ & Df & $\mathbf{P}$ \\
\hline Bağımlı & 51 & 3,1176 & ,51212 & $-2,245$ & 138 & ,026 \\
\hline Bağımsız & 89 & 3,3745 & 71874 & $-2,455$ & 131,432 & ,015 \\
\hline \multicolumn{7}{|c|}{$\begin{array}{l}\text { Muhasebe Meslek Mensuplarının E-Dönüşüm Programlarına Katılım Durumları ile E- } \\
\text { Dönüşüm Uygulamaları Yargılarına Katılım Düzeylerinin Karşılaştırılması İçin T Test } \\
\text { Tablosu }\end{array}$} \\
\hline Grup & $\mathbf{N}$ & Ortalama & Standart Sapma & $\mathrm{T}$ & Df & $\mathbf{P}$ \\
\hline Evet & 91 & 3,3846 & 69063 & 2,580 & 138 & ,011 \\
\hline Hayır & 49 & 3,0884 & ,55886 & 2,748 & 117,150 & ,007 \\
\hline
\end{tabular}

Tablo $6^{\prime}$ da ifade edilmeye çalışıldığı gibi farklı öğrenim durumuna sahip muhasebe meslek mensubunun E-Dönüşüm uygulamaları yargılarına katılım düzeyinin karşılaştırıldığı varyans analiz tablosu ile farklı E-Dönüşüm uygulamalarını kullanma düzeyine sahip muhasebe meslek mensuplarının E-Dönüşüm uygulamaları yargılarına katılım düzeyinin karşılaştırılması için varsans analizi tablosunda \%95 oranında varyansların homojen olduğu görülmüştür. Muhasebe meslek mensuplarının öğrenim durumları ile E-Dönüşüm uygulamaları yargılarına katılım düzeyinin ortalamaları arasındaki farkı belirlemek amacıyla yapılan varyans analizi sonucunda anlamlı bir farklılık olmadığı sonucuna ulaşılmıştır. Ancak muhasebe meslek mensuplarının EDönüşüm kullanım düzeyleri ile E-Dönüşüm uygulamaları yargılarına katılım düzeyinin ortalamaları arasındaki farkı belirlemek amacıyla yapılan varyans analizi sonucunda anlamlı bir farklılık olduğu sonucuna ulaşılmıştır. E-Dönüşüm uygulamalarını 'çok iyi biliyorum' ve 'iyi 
derecede biliyorum' cevabını veren muhasebe meslek mensuplarının diğer muhasebe meslek mensuplarına oranla E-Dönüşüm uygulama düzeylerinin daha yüksek olduğu tespit edilmiştir.

Tablo 6: Meslek Mensuplarının Öğrenim Düzeyleri ile E-Dönüşüm Uygulamaları Yargılarına Katılım Düzeyinin Karşılaştırılması İçin Varyans Analiz Tablosu

\begin{tabular}{|c|c|c|c|c|c|}
\hline \multicolumn{6}{|l|}{ Betimsel İstatistikler } \\
\hline Öğrenim Durumu & \multicolumn{2}{|l|}{$\mathbf{N}$} & \multicolumn{2}{|c|}{ Ortalama } & $\begin{array}{c}\text { Standart } \\
\text { Sapma } \\
\end{array}$ \\
\hline Lise & \multicolumn{2}{|c|}{37} & \multicolumn{2}{|c|}{3,0856} & ,69569 \\
\hline Yüksek Okul & \multicolumn{2}{|l|}{6} & \multicolumn{2}{|c|}{3,2222} & ,59082 \\
\hline Lisans & \multicolumn{2}{|l|}{94} & \multicolumn{2}{|c|}{3,3475} & 64753 \\
\hline Lisans Üstü & \multicolumn{2}{|l|}{3} & \multicolumn{2}{|c|}{3,7222} & ,24056 \\
\hline Toplam & \multicolumn{2}{|c|}{140} & & & \\
\hline \multicolumn{6}{|c|}{ Varyans Analiz Tablosu } \\
\hline & $\begin{array}{c}\text { Kareler } \\
\text { Toplamı } \\
\end{array}$ & Df & $\begin{array}{l}\text { Ortalama } \\
\text { Kare }\end{array}$ & $\mathbf{F}$ & $\mathbf{p}$ \\
\hline Gruplar Arası & 2,433 & 3 & ,811 & 1,893 & ,134 \\
\hline Gruplar İçi & 58,280 & 136 & ,426 & & \\
\hline Toplam & 60,713 & 139 & & & \\
\hline \multicolumn{6}{|l|}{ Betimsel İstatistikler } \\
\hline $\begin{array}{l}\text { E-Dönüşüm } \\
\text { Kullanım Düzeyi }\end{array}$ & \multicolumn{2}{|l|}{$\mathbf{N}$} & \multicolumn{2}{|c|}{ Ortalama } & $\begin{array}{c}\text { Standart } \\
\text { Sapma } \\
\end{array}$ \\
\hline Çok İyi Biliyorum & \multicolumn{2}{|c|}{20} & \multicolumn{2}{|c|}{3,6625} & ,89118 \\
\hline $\begin{array}{l}\text { İyi Derecede } \\
\text { Biliyorum }\end{array}$ & \multicolumn{2}{|c|}{61} & \multicolumn{2}{|c|}{3,4180} & ,58363 \\
\hline $\begin{array}{l}\text { İlgiliyim Ancak } \\
\text { Yeterli Bilgim Yok }\end{array}$ & \multicolumn{2}{|l|}{39} & \multicolumn{2}{|c|}{2,9615} &, 58234 \\
\hline Çok Az Bilgiliyim & \multicolumn{2}{|c|}{14} & \multicolumn{2}{|c|}{3,0417} & ,48454 \\
\hline Bilgiliyim & \multicolumn{2}{|l|}{6} & \multicolumn{2}{|c|}{3,2500} & ,28382 \\
\hline Toplam & \multicolumn{2}{|c|}{140} & & & \\
\hline \multicolumn{6}{|c|}{ Varyans Analiz Tablosu } \\
\hline & $\begin{array}{c}\text { Kareler } \\
\text { Toplamı } \\
\end{array}$ & Df & $\begin{array}{c}\text { Ortalama } \\
\text { Kare }\end{array}$ & $\mathbf{F}$ & $\mathbf{p}$ \\
\hline Gruplar Arası & 8,844 & 4 & 2,211 & 5,755 & ,000 \\
\hline Gruplar İçi & 51,869 & 135 & 384 & & \\
\hline Toplam & 60,713 & 139 & & & \\
\hline
\end{tabular}

Tablo 7'de ifade edilmeye çalışıldığı gibi farklı yaşlara sahip muhasebe meslek mensuplarının EDönüşüm uygulamaları yargılarına katılım düzeyinin karşılaştırıldığı varyans analiz tablosu ile farklı meslek deneyimine sahip muhasebe meslek mensuplarının E-Dönüşüm uygulamaları yargılarına katılım düzeyinin karşılaştırılması için varsans analizi tablosunda \%95 oranında varyansların homojen olduğu görülmüştür. Muhasebe meslek mensuplarının yaşları ile EDönüşüm uygulamaları yargılarına katılım düzeyinin ortalamaları arasındaki farkı belirlemek amacıyla yapılan varyans analizi sonucunda anlamlı bir farklılık olmadığı sonucuna ulaşılmıştır. $\mathrm{Bu}$ durum muhasebe meslek mensuplarının mesleki deneyimleri ile E-Dönüşüm uygulamaları 
yargılarına katılım düzeyinin ortalamaları arasındaki farkı belirlemek amacıyla yapılan varyans analizi sonucunda da geçerli olup, anlamlı bir farklılık olmadığı sonucuna ulaşılmıştır

Tablo 7: Meslek Mensuplarının Yaşları ile Mesleki Deneyim Düzeylerinin E-Dönüşüm Uygulamaları Yargılarına Katılım Düzeylerinin Karşılaştırılmalı Varyans Analiz Tablosu

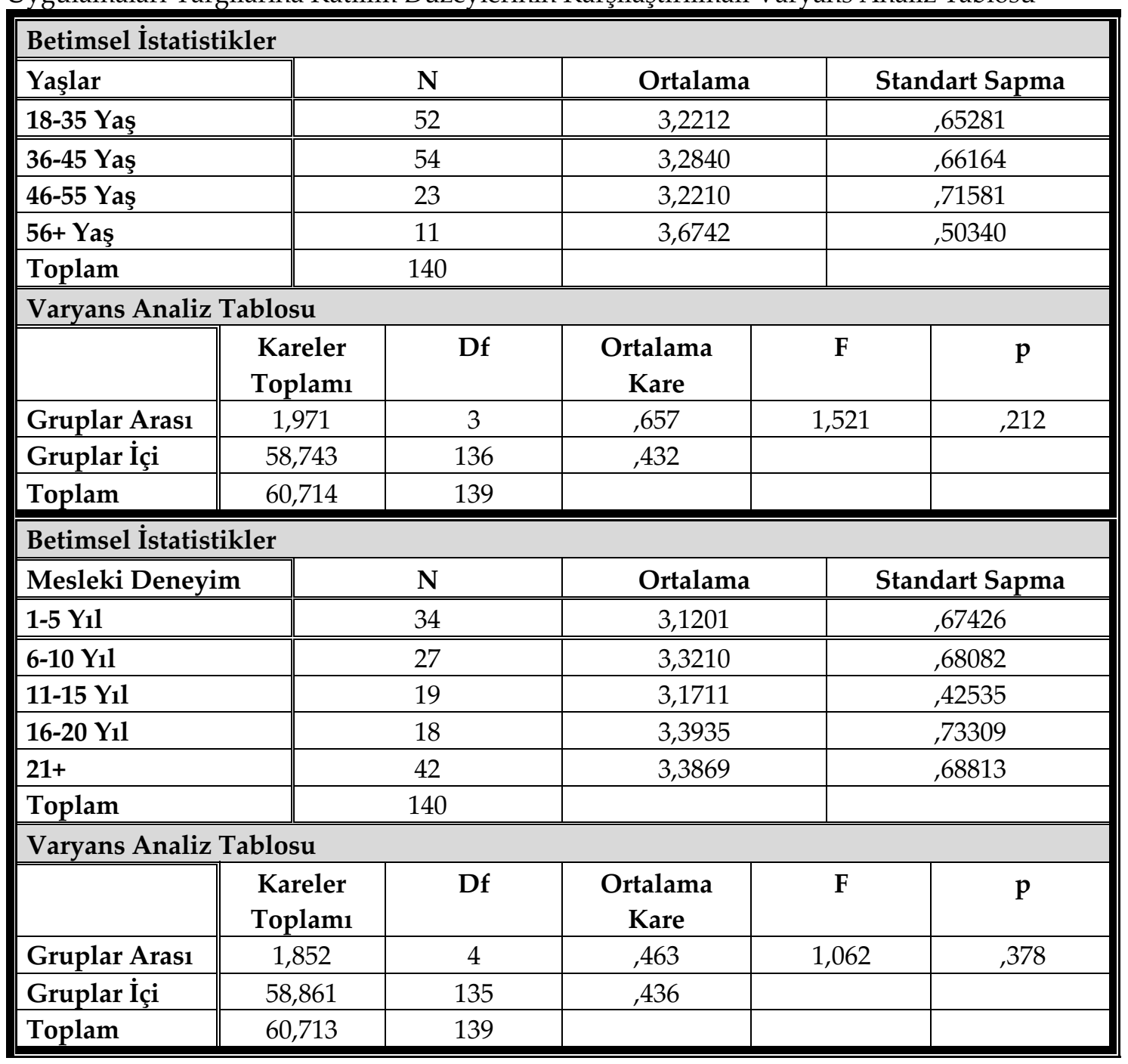

\section{SONUÇ ve ÖNERILER}

Gelişen teknoloji ve küreselleşme çabaları ülkeleri her alanda etkilemektedir. İletişim, teknoloji ve bilişim alanında yaşanan gelişmeler tüm dünyayı etkilemekte olup ülkeler arasında entegrasyonu gerekli kılmaktadır. Bu noktada muhasebe alanında da entegrasyon bir zorunluluk olarak görülmektedir. Başlangıçta değişime direnç gösterilse de değişimin getireceği kolaylıklar düşünüldüğünde işletmeler, bilgi kullanıcıları ve muhasebe meslek mensupları açısından bu değişim büyük kolaylıklar sağlamaktadır. Ülkemizde E-Sisteme geçiş çalışmaları 2000'li yıllarda eczanelerde uygulanmaya başlayan E-Reçete sistemiyle başlamış olup, süreç içinde günümüzde her alanda uygulanmaya başladığı görülmektedir. Zaman içinde altyapı sistemlerinin eksiklikleri ve bilgilerin güvenlik sorunundan oluşan aksaklıkların giderilmeye çalışılmasıyla sitemin sağladığı faydalar ön plana çıkmıştır. Çalışmada muhasebe mesleğine E-Dönüşümün sağladığı faydalar ise; 
- İnternetin olduğu her ortamda doğrudan bilgi kullanıcısına online olarak belge hazırlama imkanı tanıması,

- $\quad$ Olası vergi kayıplarının önüne geçmesi,

- Vergi otoriteleri ve etkin denetim mekanizmasını sağlamak isteyenler için gerçek bir kontrol sisteminin çalışmasını sağlaması,

- Kağıt ortamında hazırlanan belgelere göre elektronik ortamda hazırlanan belgelerin maliyetlerinin oldukça düşük olması,

- $\quad$ İşlemlerin belgelendirilme sürecinin kısa zamanda gerçekleşmesi,

- Uluslararası ticarete uyumun sağlanması,

- $\quad$ Elektronik ortamda düzenlenen belgelerin daha güvenli olarak görülmesi olarak tespit edilmiştir.

Muhasebe meslek mensuplarının yeni tebliğler kapsamında E-Dönüşüm algılarının değerlendirilmesi amacıyla Uşak Merkezde faaliyette olan 140 muhasebe meslek mensubuna yapılan anket çalışması sonucunda tespit edilen bulgular aşağıdaki gibidir:

- $\quad$ Anket çalışmasına katılan 140 muhasebe meslek mensubunun 100'nün erkek, 54'nün 36-

45 yaş aralığında, 89'nun bağımsız çalıştığı, 91'nin (64 erkek-27 bayan) eğitim programlarına katılım sağladığı, 94' nün lisans düzeyinde eğitim aldığı tespit edilmiştir.

- Muhasebe meslek mensuplarının kadın ve erkek uygulama düzeylerinin arasında anlamlı bir farklılık olmadığına ulaşılmıştır.

- Muhasebe meslek mensuplarının E-Dönüşüm uygulamaları yargılarına katılım düzeyinin karşılaştırılması sonrasında bağımlı çalışan ve bağımsız çalışan katılımcıların uygulama düzeyleri ve E-Dönüşüm uygulamaları yargılarına katılım düzeyinin karşılaştırılması sonrasında programlara katılan katılımcıların ve katılmayan katılımcıların uygulama düzeyleri arasında anlamlı bir farklılık olduğu sonucuna ulaşılmıştır.

- Muhasebe meslek mensuplarının öğrenim durumları ile E-Dönüşüm uygulamaları yargılarına katılım düzeyinin ortalamaları arasında anlamlı bir farklılık olmadığı görülmüştür.

- Muhasebe meslek mensuplarının E-Dönüşüm kullanım düzeyleri ile E-Dönüşüm uygulamaları yargılarına katılım düzeyinin ortalamaları arasında anlamlı bir farklılık olduğu sonucuna ulaşılmıştır.

Çalışmaya öneri olarak; Muhasebe meslek mensuplarının E-Dönüşüm algılarının değerlendirilmesi ve E-Dönüşüm uygulamalarında karşılaşılan sorunların belirlenebilmesi amacıyla çalışma diğer illerde faaliyetlerini sürdüren meslek mensuplarına da uygulanabilir. Özellikle konu hakkında muhasebe meslek mensuplarının sorunlarını ifade edebileceği düzenli olarak çalıstayların düzenlenmesi ve yetkili kişilerle durum değerlendirilmesinin yapılması yazar tarafından önerilmektedir.

\section{KAYNAKÇA}

Akıcı, A. ve Altun, R. (2013). Elektronik (E) Reçete Uygulaması ve Akılcı İlaç Kullanımına Katkısı, TAHUD, 17(3), 125-133.

Allahverdi, M. ve Karaer, M. (2019). E-Dönüşümün Muhasebe Mesleği Yeterlilikleri Üzerindeki Etkileri ve Türkiye'de Lisans Düzeyi Muhasebe Eğitiminin Mesleki Yeterlilikler Açısından Analizi, Muhasebe Bilim Dünyası Dergisi, 21 (1); 246-273.

Calayoğlu, İ. (2019). Elektronik Vergi Denetimindeki Teknolojik Gelişmeler ve Tam Denetime Geçiş Adımları, Muhasebe ve Finansman Dergisi, (81), 143-162. 
Çarıkçı, O. (2018). Kayıtlar ile Defterlerin Elektronik Ortamda Tutulmasının (Defter-Beyan Sistemi) Mali Müşavirler Tarafından Değerlendirilmesi, Muhasebe ve Denetime Bakış Dergisi, (55), $119-140$

Çıtak, F. ve Baskan, D.T. (2020). Muhasebe Uygulamalarındaki Elektronik Gelişmelerin Muhasebe Meslek Etiğine Etkisi: Kırıkkale İlindeki Muhasebe Meslek Mensuplarının Bakış Açısı Üzerine Bir Araştırma, Muhasebe Bilim Dünyası Dergisi, Özel Sayı 22, 249-270.

E-Defter Bilgilendirme Duyurusu, 17.02.2020 http://edefter.gov.tr/dosyalar/duyurular/e.Defter_Bilgilendirme_Duyurusu.pdf, Erişim Tarihi:10.03.2020

Elçin, R., Gerekan, B. ve Usta, M. (2018). E-Fatura, E-Defter ve E-Arşiv Uygulamalarına Geçiş Sürecinde Yaşanan Sorunlar: Serbest Muhasebeci Mali Müşavirler Üzerine Bir Araştırma, Mali Çözüm Dergisi, 146.Sayı, 13-42.

Geçkil, T. ve Tikici, M. (2015). Örgütsel Demokrasi Ölçeği Geliştirme Çalışması, Amme İdaresi Dergisi, 48 (4), 41-78.

Gökçen, G. ve Özdemir, M. (2016). Türkiye' de Muhasebe Uygulamalarında E-Defter ve E-Fatura Uygulaması, Marmara Üniversitesi Öneri Dergisi, 12 (46), 137-154.

Karasioğlu, F. ve Garip, O. (2019). E- Muhasebe Uygulamaları Kapsamında Güncel Sorunlar ve Çözüm Önerileri: Karaman'da Bir Araştırma, Selçuk Üniversitesi Sosyal Bilimler Meslek Yüksekokulu Dergisi, 22(2), 433-446.

Kılıç, S. (2012). Örnek Büyüklügü̈, Güç Kavramları ve Örnek Büyüklügü Hesaplaması, Journal of Mood Disorders, 2(3), 140-142.

Liyan, L. (2013). The Impact of Information Technology on Accounting Theory, Accounting Profession, and Chinese Accounting Education, The Twelfth Wuhan International Conference on e-Business, Association for Information Systems AIS Electronic Library (AISeL), Emerging Operations E Services Management Track, 747-753.

Madde 353 Özel Usulsüzlükler ve Cezaları, https://www.gib.gov.tr/node/83111, Erişim Tarihi: 10.03.2020

Öztürk, M. S. ve Çarıkçı, O. (2018). Büyük ve Orta Boy İşletmeler İçin Finansal Raporlama Standardının Muhasebe Meslek Mensupları Üzerinde Algı Düzeyinin Araştırılması, Mehmet Akif Ersoy Üniversitesi, İktisadi ve İdari Bilimler Fakültesi Dergisi, 5(3), 568-582.

Türker, M. (2018), Dijitalleşme Sürecinde Küresel Muhasebe Mesleğinin Yeniden Şekillenmesine Bakış Açısı, Muhasebe Bilim Dünyası Dergisi, 20 (1), 202-235.

Vergi Usul Kanunu Genel Tebliği, Sıra No:509, Resmi Gazete, Say1:30923,https://www.gib.gov.tr/sites/default/files/fileadmin/mevzuatek/vukteb509.pdf, Erişim Tarihi:12.02.2020

Vergi Sirküleri, NO: 2019/124, https://www.verginet.net/dtt/11/Vergi-Sirkuleri-2019-124.aspx, Erişim Tarihi:12.02.2020 